\begin{tabular}{|l|l|l||}
\hline \multicolumn{2}{|c|}{ PublisherInfo } \\
\hline \hline PublisherName & $:$ & BioMed Central \\
\hline \hline PublisherLocation & $:$ & London \\
\hline \hline PublisherImprintName & $:$ & BioMed Central \\
\hline \hline
\end{tabular}

\title{
Acid-base changes during acute normovolaemic hemodilution
}

\begin{tabular}{|l|l|l||}
\hline \multicolumn{2}{|c||}{ ArticleInfo } \\
\hline \hline ArticleID & $:$ & 4268 \\
\hline \hline ArticleDOI & $:$ & $10.1186 /$ ccf-2001-2921 \\
\hline \hline ArticleCitationID & $:$ & 2921 \\
\hline \hline ArticleSequenceNumber & $:$ & 56 \\
\hline \hline ArticleCategory & $:$ & Paper Report \\
\hline ArticleFirstPage & $:$ & 1 \\
\hline ArticleLastPage & $:$ & 4 \\
\hline \hline & & RegistrationDate : 2001-1-16 \\
\hline ArticleHistory & $:$ & OnlineDate \\
\hline \hline ArticleCopyright & $:$ & Biomed Central Ltd2001-16 \\
\hline \hline ArticleGrants & $:$ & \\
\hline \hline ArticleContext & $:$ & 1305433 \\
\hline \hline
\end{tabular}


Aff1 Southampton General Hospital, UK

\section{Keywords}

acid base balance, colloid infusion, hyperchloraemia, Stewart approach

\section{Comments}

This study found a slight but significant acidosis after acute normovolaemic haemodilution (ANH) with both colloids. The acidosis was metabolic in origin and may have been related to dilution of bicarbonate in the extracellular fluid (ECF). Indeed there was excellent correlation between the predicted and calculated amount of bicarbonate in the ECF after ANH. Similarly chloride concentration showed good correlation with predicted values. However, this model does not account for the effect of albumin on acid-base balance. An alternative method for explaining acid-base changes is the Stewart model, although this did not adequately explain the decrease in bicarbonate in the hydroxyethyl starch (HES) group. This may be because the Stewart model oversimplifies the presence of different anionic charges of synthetic albumin molecules. These data suggest that a small but significant degree of acidosis occurs with ANH and is caused by the dilution of bicarbonate and an accompanying hyperchloraemia. This seems to be at odds with two other publications in the same journal suggesting that changes in chloride concentration are of primary importance.

\section{Introduction}

ANH is frequently performed yet the acid-base consequences of this process have not been studied. ANH may be expected to produce acid-base changes by virtue of withdrawing bicarbonate and by infusing anions and cations. This study seeks to theoretically predict changes in anions and cations and to use the Stewart approach to evaluate the effect of changes in albumin on acid-base balance. The study also aims to evaluate acid-base changes during ANH in a prospective, randomised clinical study.

\section{Methods}


- 20 female patients scheduled for radical hysterectomy with ANH used as a blood saving method were studied

- 10 patients were randomised to receive $6 \% \mathrm{HES}\left(\mathrm{Na}^{+} 154 \mathrm{mM}\right.$ and $\left.\mathrm{Cl}^{-} 154 \mathrm{mM}\right)$

- 10 patients randomised to receive $5 \%$ albumin solution (HA) $\mathrm{Na}^{+} 158 \mathrm{mM}, \mathrm{Cl}^{-} 150 \mathrm{mM}$, octanoate $4 \mathrm{mM}, \mathrm{N}$-acetyltryptophanate $4 \mathrm{mM}$

- General anaesthesia was induced and end tidal $\mathrm{CO}_{2}$ maintained as close as possible to $40 \mathrm{mmHg}$

- Measurements were taken for haematocrit (Hct), plasma volume, red cell volume, arterial blood gases, serum sodium, potassium, chloride, calcium, lactate, and phosphate

- Measurements taken at baseline and then blood was withdrawn at $60 \mathrm{ml} / \mathrm{min}$ and replaced with HA or HES

- 20 min after target Hct of $22 \%$ was acheived, the measurements were repeated

- Plasma volume was calculated using a dye dilution method with indocyanine green. Red blood cell volume was determined using radiolabelled autologous red blood cells

\title{
Results
}

- Blood removed and colloid infused was significantly greater in the HES group due to a greater body weight in this group

- Albumin decreased by $50 \%$ in the HES group after ANH

- Base excess and bicarbonate decreased significantly in both groups

- Protein decreased in the HES group but not the HA group

- Chloride significantly increased in both groups $(+3 \mathrm{mM}$ in the HA group and $+6 \mathrm{mM}$ in the HES groups)

- In both groups the calculated mean values for bicarbonate and Chloride differed only slightly from the calculated predicted values

\section{Additional information}

\author{
Scheingraber S, Rehm M, Schmisch C, Finsterer U: Rapid saline infusion produces
} hyperchloremic acidosis in patients undergoing gynecological surgery. Anesthesiology 1999, 90:1265-1270. 
Waters $\mathrm{JH}$, Bernstein $\mathrm{CA}$ : Dilutional acidosis following hetastarch or albumin in healthy volunteers. Anesthesiology 2000, 93: 1184-1187.

Liskaser FJ, Bellomo R, Hayhoe M, Story D, Poustie S, Smith B, Letis A, Bennett M: Role of pump prime in the etiology and pathogenesis of cardiopulmonary bypass-associated acidosis.

Anesthesiology 2000, 93:1170-1173.

There is also an accompanying Editorial View

Prough DS: Acidosis associated with perioperative saline administration. Dilution or delusion? Anesthesiology 2000, 93:1167-1169.

\section{References}

1. Rehm M, Orth V, Scheingraber S, Kreimeier U, Brechtelsbauer H, Finsterer U: Acid-base changes caused by $5 \%$ albumin versus $6 \%$ hydroxyethyl starch solution in patients undergoing acute normovolemic hemodilution. A randomized prospective study. Anesthesiology. 2001, 93: 1174-1183.

This PDF file was created after publication. 